\title{
Correspondence
}

\section{Christian Realism}

To the Editors: The reassessments of neo-orthodox "Realisin" in your June issue brought to mind the debate carried on against Reihhold Niebuhr by his leading Christian pacifist contemporary, A. J. Muste. Muste's position was one of Quaker and liberal Protestant idealism infused with Gandhian revolutionism, and though not the theological heavyweight that Niebuhr was, his political astuteness and pacifist commitment lent themselves to a formidable critique of Niebuhr's "Realism." Two of these articles of Muste's are contained in Nat Hentoff's The Essoys of A. J. Muste (Indianapolis, 1967). Muste called Christian Realism a "theology of Despair" and upbraided Niebuhr for proclaiming a fatalistic emphasis on the hopelessness of Man's estate. Referring to Niebuhr, he wrote: "Though he recognizes love as a sort of ultinate, in practice he does not accept Martin Buber's counsel [an oft-repeated reference of Muste's] that, difficult as it may be, our task is precisely to drive the plowshare of the normative principlei.e., love-into the hard soil of political reality." I think A. J. would have been pleased to see Charles McCulloch's article "Up to Our Steeples in Realism."

Miluoukee, Wis.

Joseph McCarty

\section{Re: Ziken Mizuto}

To the Editors: Peter Berger pricks out an interesting new contour for the future in "Projekt Wassertor" (Worldoiew, July, 1973). The whole thing was devised by the multinational corporations which control our government, and are in turn controlled by the West German tourist industry, in order to create interest and make Washington an exciting place for tourists to visit. Our destiny, he concludes, is no longer to be the world's policeman but its entertainer.

But in fact Watergate is the penultimate domino, planned and executed by the giant trading companies-Mitsubishi, Tokyomenka; et al.-which lined us up, all in a row, so that, at the end, only Superdomino will remain standing. Already advance parties of these rival organizations are jockeying for position at either coast; the real crisis will come when vast hordes of German and Japanese "tourists" confront each other at mid-continent.

Our destiny, it would seem, is to be neither policeman nor entertainer. The North American Continent, after centuries of isolation, will be the arena for the'final face-off between the victors of World War II. And Neuhaus was right! Our own development will follow the Peruvian model-simply directing traffic and providing uniformed doormen for the contending soldiery.

Malcolm Monroe

White Plains, N.Y.

To the Editors: The United States, pre-Watergate, was just not suffciently interesting for tourists, says Peter Berger. From out left off the American political spectrum, however, Nixon-watching has always been interesting, if ambiguous. Outrage frustrated, commingled with a perverse and gossipy pleasure at so classic a specimen of human sinfulness.

Now, in the eerie off-color of Watergate, what was ambiguous becomes paradoxical and outright contradictory. Fascination with Nixon's left profile is both exciting and depressing. I for one am enjoying reading the newspapers again, It is frankly exciting to see in establishment headlines what was formerly restricted to the underground press. But it is equally depressing to see in living color, to hear for deadly hours of dull, monotonous droning, the ghastly human waste from this malignant corruption. Watergate is at once therapentic and frustrating. It transposes the decadence of American public life into symbols that can outrage consensus Americans.

But what are we outraged at? Petty burglary, gossipy snooping, low-level political harassment? And at whom? "The White House," "at that point in time" (whoever and whatever that is)? But what of the gross outrages-Christmas bombings, ITT-CIA's Chilean counterrevolution, the grain deal, rape of the Constitution, systematic extortion of individ. ual liberties-of which Watergate is but a sensational symptom?

There is a heartening and yet terrifying parado $\mathrm{x}$ in Watergate. Is it not encouraging that little men, whether motivated by good intentions, like Ellsberg, or by self-interest like McCord, can bring this massive, world-encompassing, selfgenerated madness to a halt?

And it is both pleasant and sobering at the same time, I for one am enjoying indulgence in righteous indignation. We on the Left have been listed, manipulated, spied upon and bullied, and everyone is at least a little disturbed. Having myself lived on the left fringe of North Carolina, Tennessee, Georgia and Connecticut, there is an obvious and overdue pleasure at being championed by Ervin, Baker, Talmadge and Weicker.

We have heard rumblings among those on the Left that the last national Presidential campaign finally proved the incompatibility of moral concerns and American politics. Nonsensel The wake from Watergate proves them indissoluble. I am bolstered in this conviction.

Yet the abysmal amorality of these Watergatians, their droning recita(Continued on p. 62) 